\title{
The Nuclear DNA Content Determination of 31 Endemic Freshwater Fishes in Korea
}

\author{
In-Seok Park
}

Division of Convergence on Marine Science, College of Ocean Science and Engineering, Korea Maritime \& Ocean University, Busan 49112, Korea

Received: February 18, 2021

Revised: February 26, 2021

Accepted: March 2, 2021

${ }^{+}$Corresponding author In-Seok Park

Division of Convergence on Marine Science, College of Ocean Science and Engineering, Korea Maritime \& Ocean University, Busan 49112, Korea.

Tel: +82-51-410-4321

E-mail: ispark@kmou.ac.kr

Copyright @ 2021 The Korean Society of Developmental Biology.

This is an Open Access article distributed under the terms of the Creative Commons Attribution Non-Commercial License (http://creativecommons.org/licenses/ by-nc/4.0/) which permits unrestricted non-commercial use, distribution, and reproduction in any medium, provided the original work is properly cited.

ORCID

In-Seok Park

https://orcid.org/0000-0001-5990-5320

Conflict of interests

The authors declare no potential conflict of interest.

\section{Acknowledgements}

This manuscript was remarkably improved by comments from anonymous reviewers. I am grateful for assistance of the staff of the Fishery Genetics and Breeding Sciences Laboratory of the Korea Maritime \& Ocean University (KMOU), Korea.

\section{Authors' contributions}

The article is prepared by a single author.

\section{Ethics approval}

This study completed both the guidelines for securing the research ethics of the Ministry of Education (Article 15 of the Academic Promotion Act) and the standards of the Act on Laboratory Animals of the Ministry of Food and Drug

\section{Abstract}

The main purpose of the current study was to obtain nuclear DNA content data among the representatives of the families and subfamilies of 31 endemic fishes that inhabit river of Korea. DNA contents of 31 endemic species were observed to rang from 1.5 to $4.8 \mathrm{pg}$ DNA/ nucleus. In Cyprinidae, DNA content of Abbottina springeri (1.5 \pm 0.03 pg DNA/nucleus) was the lowest value and DNA content of Carassius cuvieri (4.5 $\pm 0.32 \mathrm{pg}$ DNA/nucleus) was the highest value in all experimental groups. In Cobitidae, DNA content of Iksookimia longicorpa (3.9 $\pm 0.17 \mathrm{pg}$ DNA/nucleus) was the highest value and DNA content of Orthrias toni $(1.5 \pm 0.18$ pg DNA/nucleus) was the lowest value in all experimental groups. This study provides new information for a better understanding of the process of genomic evolution in 31 endemic species in river of Korea.

Keywords: Amblycipitidae, Cyprinidae, Cobitidae, Cottidae, DNA content, Flow cytometry

\section{INTRODUCTION}

In general, more specialized or evolutionarily advanced fishes usually have less DNA than the more generalized forms. There are, however, several exceptions that may represent fish groups which are now in the process of evolutionary radiation (Hinegardner \& Rosen, 1972). According to Kim et al. (1995), in a given individual, the correlation logically ensues between the nuclear DNA amount and the karyotype, namely the number and shape of the chromosome characteristic of the species. In general, studies of nuclear DNA content in living organisms in fish particularly have been performed using Feulgen-stained blood smears and microdensitometry analysis (Oliveira et al., 1992, 1993a, 1993b; Carvalho et al., 2002), or blood cell samples in suspension, which were stained with base-specific fluorochromes and analyzed by flow cytometry (Tiersch et al., 1989a, 1989b, 1990; Carvalho et al., 2002).

Flow cytometry has various forms of clinical applications in oncology for understanding surface expression, intracellular signaling, cell cycle content analysis, and a number of other interesting parameters (Vanparys et al., 2006; Park, 2019, 2020; Park \& Choi 2020). Recent developments in instrument platforms, calibration methods, and reagent quality have now made flow cytometry a valuable tool for DNA content analysis (Estevam et al., 2011; Goo et al., 2018; Park, 2019, 2020; Park \& Choi 2020). These calibration packages can detect whether the parameters are within acceptable ranges and thus allow for consistent sample acquisition over time. One of the advantages of flow 
Safety (Law No. 1601), including the Research Ethics of the Korea Maritime \& Ocean University (KMOU), Korea. cytometry is the promptness of the measurement, making it possible to measure thousands of cells over a short period of time, and the ability for multi-color immunophenotyping (Estevam et al., 2011; Goo et al., 2018).

However, no fishes have been examined to have their nuclear DNA content so far among 200 species of endemic fish species that live in the rivers of Korea (Byeon et al., 2010). The enormous diversity of nuclear DNA content observed among fish led Ohno (1974) to suggest that comparative studies of the karyotype of different fish groups would make no sense if they were not followed by the information regarding change in genome size. This work is based on data gathered from analyses of 31 endemic species of fishes that appear in the river of Korea and is part of an overall study of cellular DNA content in the animal kingdom.

\section{MATERIALS AND METHODS}

On June 2019, samples of 31 endemic species (16 Cyprinidae, 13 Cobitidae, 1 Cottidae, and 1 Amblycipitidae) were trapped in the Hantan River (Fig. 1a: Gomun-ri, Yeoncheon-eup,

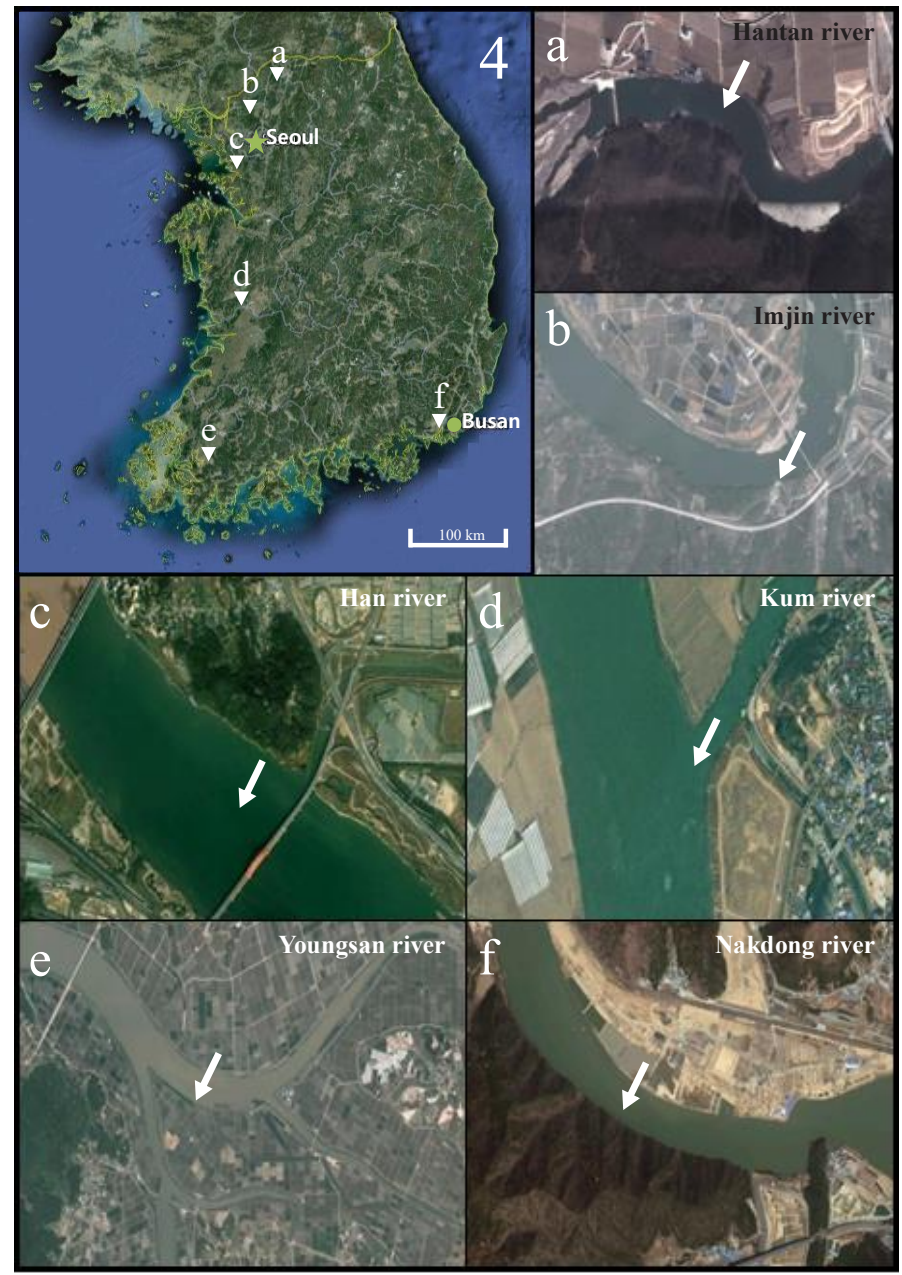

Fig. 1. Sampling location of $\mathbf{3 1}$ endemic species among major rivers of Korea on Korean map (white arrow heads) and satellite map (white arrows). Hantan river (a); Imjin river (b); Han river (c); Kum river (d); Youngsan river (e); and Nakdong river (f). Adapted from Goo et al. (2018) with CC-BY-NC. 
Yeoncheon-gun, Gyeonggi-do, Korea [ $38^{\circ} 03^{\prime} 41.29^{\prime \prime} \mathrm{N}, 127^{\circ} 07^{\prime} 20.80^{\prime \prime}$ E]), Imjin River (Fig. 1b: Wondang-ri, Jangnam-myeon, Yeoncheon-gun, Gyeonggi-do, Korea [ $37^{\circ} 57^{\prime} 57.82^{\prime \prime} \mathrm{N}, 126^{\circ} 53^{\prime}$

15.11" E]), Han River (Fig. 1c: Haengjue-dong, Deokyang-gu, Goyang-city, Gyeonggi-do, Korea

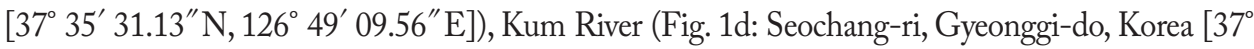
$35^{\prime} 31.13^{\prime \prime} \mathrm{N}, 126^{\circ} 49^{\prime}$ 09.56" E]), Yongsan River (Fig. 1e: Sinhak-ri, Sihong-myeon, Yeongam-gun,

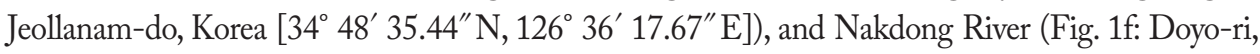
Saengnim-myeon, Gimhae-city, Gyeongsangnam-do, Korea [ $\left.35^{\circ} 21^{\prime} 55.21^{\prime \prime} \mathrm{N}, 128^{\circ} 53^{\prime} 13.39^{\prime \prime} \mathrm{E}\right]$ ) (Fig. 1, According to Goo et al., 2018). The measurement of standard length and body weight were taken to the nearest $0.01 \mathrm{~cm}$ and $0.01 \mathrm{~g}$ using digital vernier calipers (CD-20CP; Mitutoyo, Kawasaki, Japan) and electronic balance (Shimadzu, Kyoto, Japan) in all samples. Collected samples fixed in 70\% ethanol (Sigma-Aldrich, St. Louis, MO,USA) and 70\% ethanol of each sample were exchanged after 24 hours.

DNA content analysis was performed using flow cytometry (PA- II, Partec, Munich, Germany). Ventral fins from each fishes were analyzed using flow cytometry measurement. For flow cytometric analysis, tissues of ventral fin were homogenized and filted using $30 \mu \mathrm{m}$ filter, after that centrifugation (Centrifuge Micro 17R, Hanil Science Industrial, Incheon, Korea; 12,000×g, 10 min). And removed supernatant liquid and added $0.5 \mathrm{~mL}$ CyStain DNA 2 step nuclei extraction buffer (CyStain DNA 2 step high resolution DNA staining kit, Partec) and 2 mL CyStain DNA 2 step staining buffer (CyStain DNA 2 step high resolution DNA staining kit, Partec).

The tail fin tissue with $1.7 \mathrm{pg}$ DNA/nucleus of marine medaka, Oryzias dancena were used as a standard reference (Park et al., 2016; Park, 2021) in this experiment. The marine medaka isn't indigenous to Korea. However, this species is accredited by the Ministry of Land, Transport and Maritime Affairs, Korea (Ordinance of Agriculture, Food and Fisheries, No. 1) and is imported legally from Indonesia (Kim et al., 2009a, 2009b; Park, 2021). The experiment was performed in triplicate and the results are reported as means $\pm S E$ ( $n=50)$, unless otherwise stated.

\section{RESULTS AND DISCUSSION}

Hinegardner \& Rosen (1972) proposed the following combination of items to explain the noted distribution of DNA in the Teleostei. There are three possible changes that could be associated with DNA during the evolution; (1) The amount of DNA could remain constant and be modified by mutation or recombination, (2) it could increase by duplication, or (3) it could decrease. All these changes have occurred, both separately and in combination. A combination of mutation, recombination, and natural selection is perhaps the foundation for speciation (Hinegardner \& Rosen, 1972).

The results obtained among the species of 31 analyzed endemic species are shown in Table 1 and Fig. 2. DNA contents of 31 endemic species were observed to span from 1.5 to $4.8 \mathrm{pg}$ DNA/ nucleus. As shown in Table 1 and Fig. 2, In Cyprinidae, DNA content of Abbottina springeri $(1.5 \pm 0.03 \mathrm{pg}$ DNA/nucleus) was the lowest value in all experimental groups and DNA content of

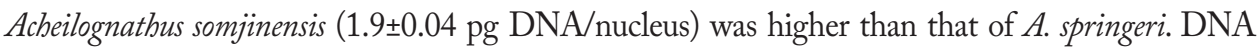
content of Carassius cuvieri ( $4.5 \pm 0.32 \mathrm{pg}$ DNA/nucleus) was the highest value in Cyprinidae groups. DNA content of Carassius cuvieri were higher than those of C. auratus (3.8 $\pm 0.41 \mathrm{pg}$ DNA/ nucleus) and Cyprinus carpio (3.6 $\pm 0.24 \mathrm{pg}$ DNA/nucleus). DNA content of $C$. auratus was higher than that of $C$. carpio, and DNA content of Abbottina rivularis (3.9 $\pm 0.18 \mathrm{pg}$ DNA/nucleus) was higher than those of C. auratus and C. carpio.

As mentioned by Kim et al. (1995), Misgurnus mizolepis has 2n=48 chromosomes, being made 
Table 1. Standard length, body weight, and DNA contents for Korean freshwater fish species in this study

\begin{tabular}{|c|c|c|c|c|}
\hline \multirow[b]{2}{*}{ Family } & \multirow{2}{*}{$\begin{array}{l}\text { Genus } \\
\text { species (Korean common name) }\end{array}$} & \multicolumn{3}{|c|}{ Measurement } \\
\hline & & $\begin{array}{l}\text { Standard length } \\
(\mathrm{cm})\end{array}$ & $\begin{array}{l}\text { Body weight } \\
\text { (g) }\end{array}$ & $\begin{array}{l}\text { DNA content } \\
\text { (pg/nucleus) }\end{array}$ \\
\hline \multirow[t]{28}{*}{ Cyprinidae } & Abbottina & & & \\
\hline & rivularis (배들매치) & $9.0 \pm 1.08$ & $20.1 \pm 2.05$ & $3.9 \pm 0.18$ \\
\hline & springeri (왜매치) & $7.1 \pm 0.87$ & $13.2 \pm 1.02$ & $1.5 \pm 0.03$ \\
\hline & Acheilognathus & & & \\
\hline & koreensis (칼납자루) & $7.8 \pm 1.20$ & $14.2 \pm 1.07$ & $2.1 \pm 0.04$ \\
\hline & somjinensis (임실납자루) & $5.4 \pm 0.91$ & $10.4 \pm 1.59$ & $1.9 \pm 0.04$ \\
\hline & Aphyocypris & & & \\
\hline & chinensis (왜몰개) & $6.1 \pm 2.58$ & $13.2 \pm 1.92$ & $2.1 \pm 0.02$ \\
\hline & Carassius & & & \\
\hline & auratus (붕어) & $61.5 \pm 7.45$ & $815.8 \pm 50.95$ & $3.8 \pm 0.41$ \\
\hline & cuvieri (떡붕어) & $70.4 \pm 5.88$ & $981.1 \pm 80.92$ & $4.5 \pm 0.32$ \\
\hline & Coreoleuciscus & & & \\
\hline & splendidus (쉬리) & $11.8 \pm 1.54$ & $22.8 \pm 1.94$ & $2.2 \pm 0.03$ \\
\hline & Cyprinus & & & \\
\hline & carpio (잉어) & $62.8 \pm 8.78$ & $804.9 \pm 92.45$ & $3.6 \pm 0.24$ \\
\hline & Gnathopogon & & & \\
\hline & strigatus (줄몰개) & $8.2 \pm 1.44$ & $18.6 \pm 2.08$ & $2.6 \pm 0.05$ \\
\hline & Gobiobotia & & & \\
\hline & naktongensis (흰수마자) & $7.5 \pm 1.25$ & $15.5 \pm 1.62$ & $2.2 \pm 0.04$ \\
\hline & Ladislavia & & & \\
\hline & taczanowskii (새미) & $12.4 \pm 1.02$ & $24.1 \pm 4.89$ & $3.3 \pm 0.01$ \\
\hline & Microphysogobio & & & \\
\hline & longidorsalis (배가사리) & $10.8 \pm 1.90$ & $24.1 \pm 3.14$ & $2.9 \pm 0.05$ \\
\hline & Rhynchocypris & & & \\
\hline & oxycephalus (버들치) & $9.5 \pm 3.88$ & $22.9 \pm 5.91$ & $3.3 \pm 0.12$ \\
\hline & Squalidus & & & \\
\hline & chankaensis (참몰개) & $10.8 \pm 2.87$ & $24.5 \pm 5.83$ & $3.4 \pm 0.14$ \\
\hline & gracilis (긴몰개) & $9.7 \pm 1.20$ & $20.5 \pm 2.74$ & $2.9 \pm 0.12$ \\
\hline \multirow[t]{15}{*}{ Cobitidae } & Cobitis & & & \\
\hline & lutheri (점줄종개) & $7.5 \pm 1.87$ & $14.6 \pm 1.09$ & $3.8 \pm 0.40$ \\
\hline & tetralineata (줄종개) & $9.8 \pm 1.02$ & $13.7 \pm 1.91$ & $4.8 \pm 0.58$ \\
\hline & Iksookimia & & & \\
\hline & choii (미호종개) & $7.5 \pm 1.90$ & $11.7 \pm 2.48$ & $3.5 \pm 0.23$ \\
\hline & hugowolfeldi (남방종개) & $10.5 \pm 2.88$ & $14.6 \pm 1.28$ & $3.7 \pm 0.07$ \\
\hline & koreensis (참종개) & $8.8 \pm 1.22$ & $14.5 \pm 2.09$ & $3.3 \pm 0.56$ \\
\hline & longicorpa (왕종개) & $9.4 \pm 2.71$ & $13.5 \pm 3.49$ & $3.9 \pm 0.17$ \\
\hline & pumila (부안종개) & $6.8 \pm 1.07$ & $10.9 \pm 3.54$ & $3.7 \pm 0.24$ \\
\hline & Koreocobitis & & & \\
\hline & naktongensis (얼룩새코미 꾸리) & $12.4 \pm 3.99$ & $20.4 \pm 5.28$ & $2.4 \pm 0.18$ \\
\hline & rotundicaudata (새코미꾸리) & $15.0 \pm 2.58$ & $18.1 \pm 4.71$ & $2.1 \pm 0.18$ \\
\hline & Misgurnus & & & \\
\hline & anguillicaudatus (미꾸리) & $12.4 \pm 3.25$ & $14.3 \pm 4.41$ & $3.6 \pm 0.15$ \\
\hline & mizolepis (미꾸라지) & $13.8 \pm 1.05$ & $15.8 \pm 2.58$ & $2.8 \pm 0.08$ \\
\hline
\end{tabular}


Table 1. Continued

\begin{tabular}{|c|c|c|c|c|}
\hline \multirow[b]{2}{*}{ Family } & \multirow{2}{*}{$\begin{array}{l}\text { Genus } \\
\text { species (Korean common name) }\end{array}$} & \multicolumn{3}{|c|}{ Measurement } \\
\hline & & $\begin{array}{l}\text { Standard length } \\
(\mathrm{cm})\end{array}$ & $\begin{array}{l}\text { Body weight } \\
\text { (g) }\end{array}$ & $\begin{array}{l}\text { DNA content } \\
\text { (pg/nucleus) }\end{array}$ \\
\hline \multirow[t]{4}{*}{ Cobitidae } & Niwaella & & & \\
\hline & multifasciata (수수미꾸리) & $13.1 \pm 1.44$ & $16.8 \pm 3.66$ & $2.6 \pm 0.20$ \\
\hline & Orthrias & & & \\
\hline & toni (종개) & $08.9 \pm 1.48$ & $12.8 \pm 1.59$ & $1.5 \pm 0.18$ \\
\hline \multirow[t]{2}{*}{ Cottidae } & Cottus & & & \\
\hline & hangiongensis (한둑중개) & $11.4 \pm 2.08$ & $18.8 \pm 4.81$ & $1.9 \pm 0.08$ \\
\hline \multirow[t]{2}{*}{ Amblycipitidae } & Liobagrus & & & \\
\hline & andersoni (퉁가리) & $10.2 \pm 2.26$ & $20.4 \pm 2.43$ & $2.2 \pm 0.19$ \\
\hline
\end{tabular}

Each value are average values of triplicate experiments $(n=50)$.

DNA contents (pg/nucleus): Standard control used was fin cell of marine medaka, Oryzias dancena (1.71 pg/nucleus: According to Park et al., 2016).

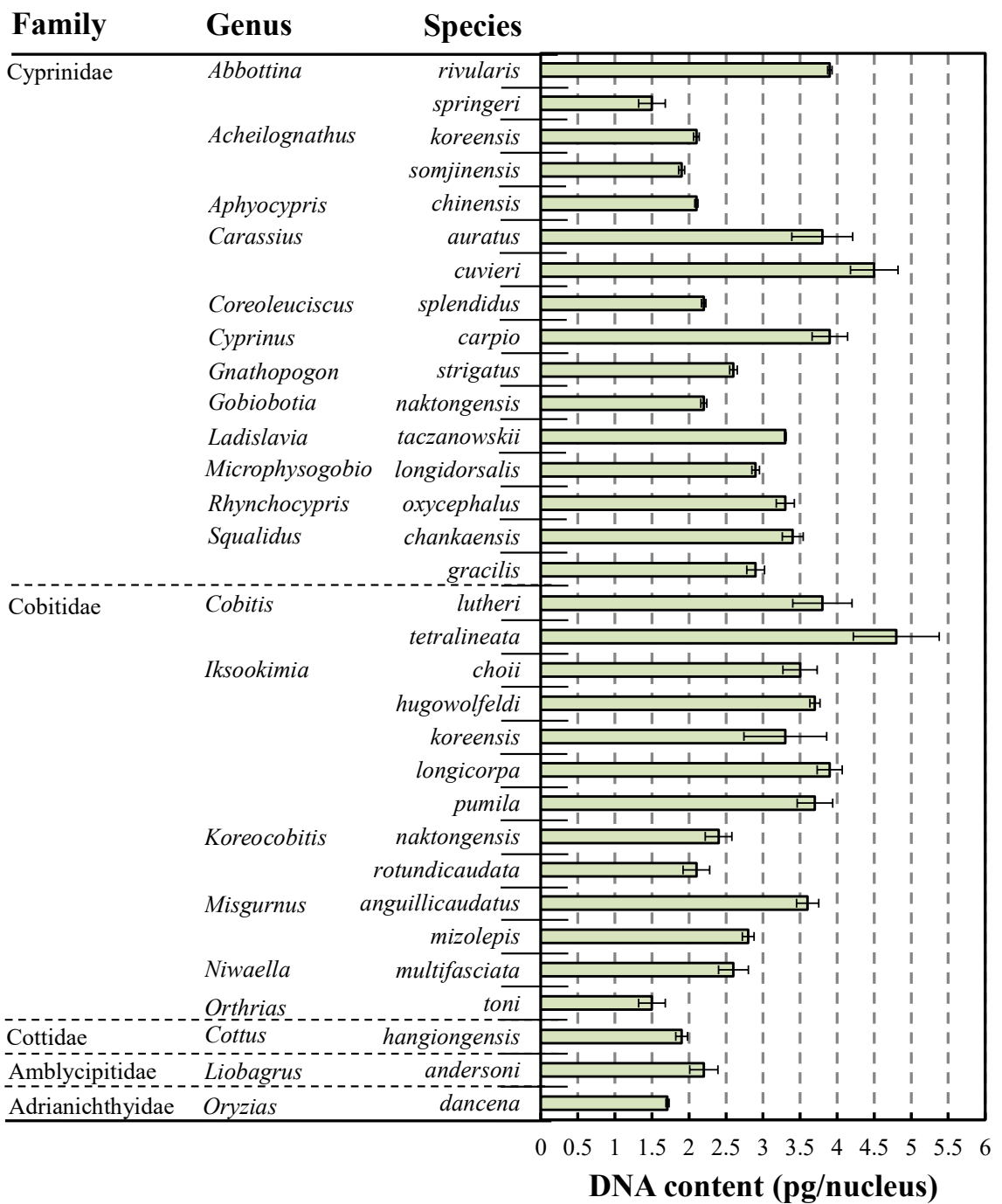

Fig. 2. The mean value of DNA contents on Korean freshwater fish species from ventral fin tissues used in this experiment. The mean peak value of standard control (marine medaka, Oryzias dancena) is approximately $1.71 \pm 0.04 \mathrm{pg} / \mathrm{nucleus}$ (According to Park et al., 2016). Each value are average values of triplicate experiments $(n=50)$. Error bars are standard deviation values of triplicate experiments $(n=50)$. 
of 12 metacentric (M), 4 submetacentric (SM), and 32 acrocentric (A) chromosomes, and $M$. anguillicaudatus has $2 \mathrm{n}=50$ chromosome, consisting of $10 \mathrm{M}, 4 \mathrm{SM}$, and $36 \mathrm{~A}$ chromosomes. Both species has an arm number (NF) of 64. As mentioned Nam et al. (1998), Cyprinus carpio had 2n=100 diploid chromosomes, comprising $12 \mathrm{M}, 40 \mathrm{SM}$, and 48 A chromosomes, and diploid chromosome number of Carassius auratus was also $2 \mathrm{n}=100$, just as the karyotype of C. carpio and C. auratus, which has $12 \mathrm{M}, 36 \mathrm{SM}$, and $52 \mathrm{~A}$ chromosomes in Japan. DNA contents of $M$. anguillicaudatus and C. carpio were higher than those of $M$. mizolepis and C. auratus, respectively. Metacentric chromosome numbers of $M$. anguillicaudatus and $C$. carpio were lower than those of $M$. mizolepis and $C$. auratus respectively. In addition, acrocentrics numbers of $M$. anguillicaudatus and $C$. carpio were higher than those of M. mizolepis and C. auratus.

As shown in Table 1 and Fig. 2, in Cobitidae, DNA content of Cobitis tetralineata was the highest value (4.8 $\pm 0.58 \mathrm{pg} \mathrm{DNA} /$ nucleus) and Orthrias toni was the lowest value $(1.5 \pm 0.18 \mathrm{pg}$ DNA/nucleus) in all experimental groups. In genus Iksookimia, DNA content of 5 species were observed to rang from $3.3 \mathrm{pg} \mathrm{DNA} /$ nucleus (I. koreensis) to $3.9 \mathrm{pg} \mathrm{DNA} /$ nucleus (I. longicorpa). In genus Misgurnus, DNA content of $M$. anguillicaudatus (3.6 $\pm 0.15 \mathrm{pg}$ DNA/nucleus) was lower than that of $M$. mizolepis (2.8 $\pm 0.08 \mathrm{pg}$ DNA/nucleus).

DNA contents of Cottus hangiongensis in Cobitidae and Liobagrus andersoni in Amblycipitidae were $1.9 \pm 0.08 \mathrm{pg}$ DNA/nucleus and $2.2 \pm 0.19 \mathrm{pg}$ DNA/nucleus each (Table 1 and Fig. 2). As a result, DNA content was observed to range from 1.5 to $4.8 \mathrm{pg}$ DNA/nucleus in all freshwater fishes in Korea. In the same family and the same genus groups, DNA contents of larger species don't have higher value than those of smaller species in every case. So, DNA content was unrelated to morphometric characteristics (standard length and body weight) in the same family and the same genus groups.

Among vertebrates, DNA content has been observed to span from 0.78 to 280.00 pg per diploid nucleus (Olmo et al., 1989; Carvalho et al., 2002). Among fishes, DNA content spans from 0.78 pg per diploid nucleus in Tetraodon fuviatis (Hinegardner \& Rosen, 1972; Carvalho et al., 2002) to 248.00 pg in Lepidosiren paradoxa (Ohno \& Atkin, 1966; Carvalho et al., 2002). The data acquired by Hinegardner \& Rosen (1972) on 275 teleostei showed that there is a clear modal value of about $2.0 \mathrm{pg}$ of DNA per diploid nucleus. However, the differences greater over twice in DNA content may be found among specimens of the same family or even of the same genus, as is the case of Cyprinids of the genus Barbus (Ohno et al., 1967; Wolf et al., 1969; Carvalho et al., 2002) and species of the genus Corydoras (Hinegardner \& Rosen, 1972; Oliveira et al., 1992; Carvalho et al., 2002). Although some authors have suggested that this variation should be related to the number of genes in the organisms or to the complexity of their development (Cavalier-Smith, 1978; Carvalho et al., 2002), many agree that there is no significant correlation between the amount of nuclear DNA and the organic or genetic complexity (Cavalier-Smith, 1978; Carvalho et al., 2002). In addition, this study is of no significant correlation between DNA content and organic complexity (standard length and body weight).

As mentioned by Hardie \& Hebert (2004), genome size diversity in ray finned fishes is not related to metabolic rate and organic complexity, but is obviously correlated with egg diameter, suggesting linkages to the evolution of parental care. Hinegardner \& Rosen (1972) have observed that specialized fishes had smaller genomes than more generalized forms, and this trend was supported in the subsequent studies (Cimino, 1974). This pattern may reflect decreases in chromosome number and genome size in specialized species, or constraints on genome size related to the heightened developmental complexity of specialized species (Hardie \& Hebert, 2004). Thus, the analysis of nuclear DNA content raises a problem for evolutionary genetics regarding the interpretation of this quantitative variation in genome size or in DNA amount (Gold \& Price, 
1985; Carvalho et al., 2002).

Our current investigation can be utilized as a foundation for continued cytogenetic studies of freshwater fishes in Korea for species classification or maintenance, as well as to provide basic data for commercial production of new species. Moreover, further extensive studies are needed to get more complete information on the evolutionary direction and detailed genetic relationship among freshwater fishes in Korea by conducting chromosome analysis, detecting nucleolus-organizer regions, and analyzing chromosome in situ hybridization.

\section{CONCLUSION}

In conclusion, this result suggests that DNA content is related to chromosome number. However, I am not entirely sure of this conclusion, because the other 27 endemic species from 31 species in this study inhabiting were not fully analyzed karyotype yet. So, future research need to investigate unknown karyotype analysis of 27 endemic species in Korea, and the investigation of relationship between chromosome and DNA content is necessary as well.

\section{REFERENCES}

Byeon MS, Lee GY, Lee JY, Yang HJ (2010) Distribution and Genetic Differentiations of Korea Endemic Species (Freshwater Fishes) in Four Major Rivers. National Institute of Environmental Research, Incheon, Korea, Report No. NIER-2010-18-1193.

Carvalho ML, Oliveira C, Navarrete MC, Froehlich O, Foresti F (2002) Nuclear DNA content determination in Characiformes fish (Teleostei, Ostariophysi) from the Neotropical region. Genet Mol Biol 25:49-55.

Cavalier-Smith T (1978) Nuclear volume control by nucleoskeletal DNA, selection for cell volume and cell growth rate, and the solution of the DNA C-value paradox. J Cell Sci 34:247-278.

Cimino MC (1974) The nuclear DNA content of diploid and triploid Poeciliopsis and other Poeciliid fishes with reference to the evolution of unisexual forms. Chromosoma 47:297-307.

Estevam J, Danaee H, Liu R, Ecsedy J, Trepicchio WL, Wyant T (2011) Validation of a flow cytometry based $\mathrm{G}_{2} \mathrm{M}$ delay cell cycle assay for use in evaluating the pharmacodynamic response to Aurora A inhibition.J Immunol Methods 363:135-142.

Gold JR, Price HJ (1985) Genome size variation among North American minnows (Cyprinidae). I. Distribution of the variation in five species. Heredity 54:297-305.

Goo IB, Lim SG, Gill HW, Park IS, Choi CY (2018) Cytogenetic characteristics of Cyprinidae between diploid and spontaneous triploid in major river of Korea.J Mar Life Sci 3:9-21.

Hardie DC, Hebert PDN (2004) Genome size evolution in fishes. Can J Fish Aquat Sci 61:16361646.

Hinegardner R, Rosen DE (1972) Cellular DNA content and evolution of teleostean fishes. Am Nat 106:621-644.

Kim DS, Nam YK, Bang IC, Song HY (2009a) Early gonadogenesis and sex differentiation of marine medaka, Oryzias dancena (Beloniformes; Teleostei). Korean J Ichthyol 21:141-148.

Kim DS, Nam YK, Bang IC, Song HY (2009b) Embryogenesis and early ontogenesis of a marine medaka, Oryzias dancena. Korean J Ichthyol 21:227-238.

Kim DS, Nam YK, Park IS (1995) Survival and karyological analysis of reciprocal diploid and triploid hybrids between mud loach (Misgurnus mizolepis) and cyprinid loach (Misgurnus 
anguillicaudatus). Aquaculture 135:257-265.

Nam YK, Oh SY, Jo JY, Kim DS (1998) Cytogenetic analysis of induced hybrid between common carp (Cyprinus carpio) and crucian carp (Carassius auratus). Korean J Aquacult 11:77-81.

Ohno S (1974) Chordata 1 - Protochordata, Cyclostomata and Pisces. In Bernard J (ed), Vol. 4. Gebrüder Borntraeger, Berlin.

Ohno S, Atkin NB (1966) Comparative DNA values and chromosome complements of eight species of fishes. Chromosoma 18:455-466.

Ohno S, Muramoto J, Christian L, Atkin NB (1967) Diploid - tetraploid relationships among oldworld members of the fish family Cyprinidae. Chromosoma 23:1-9.

Oliveira C, Almeida-Toledo LF, Mori L, Toledo Filho SA (1992) Extensive chromosomal rearrangements and nuclear DNA content changes in the evolution of the armoured catfishes genus Corydoras (Pisces, Siluriformes, Callichthyidae).J Fish Biol 40:419-431.

Oliveira C, Almeida-Toledo LF, Mori L, Toledo Filho SA (1993a) Cytogenetic and DNA content studies on armoured catfishes of the genus Corydoras (Pisces, Siluriformes, Callichthyidae) from the Southeast coast of Brazil. Braz J Genet 16:617-629.

Oliveira C, Almeida-Toledo LF, Mori L, Toledo Filho SA (1993b) Cytogenetic and DNA content in six genera of the family Callichthyidae (Pisces, Siluriformes). Caryologia 46:171-188.

Olmo E, Capriglione T, Odierna G (1989) Genome size evolution in vertebrates: Trends and constrains. Comp Biochem Physiol 92B:447-453.

Park IS (2019) A comparative analysis of cell cycles in diploid and induced triploid tissues in marine medaka (Oryzias dancena). Korean J Environ Biol 37:735-740.

Park IS (2020) A flowcytometric method for DNA content analysis of Pacific abalone, Haliotis discus hannai cell. Korean J Environ Biol 38:248-253.

Park IS (2021) A review of studies on Oryzias dancena. Lab Anim Res 37:4.

Park IS, Choi HJ (2020) Nuclear DNA content determination of 15 seawater shellfishe species in Korea. Korean J Environ Biol 38:343-349.

Park IS, Gil HW, Lee TH, Nam YK, Ko MG, Kim DS (2016) Cytogenetic study of diploid and triploid marine medaka, Oryzias dancena. Korean J Ichthyol 28:215-222.

Tiersch TR, Chandler RW, Kallman KD, Wachtel SS (1989a) Estimation of nuclear DNA content by flow cytometry in fishes of the genus Xiphophorus. Comp Biochem Physiol 94:465-468.

Tiersch TR, Chandler RW, Wachtel SS, Elias S (1989b) Reference standards for flow cytometry and application in comparative studies of nuclear DNA content. Cytometry 10:706-710.

Tiersch TR, Simco BA, Davis KB, Chandler RW, Wachtel SS, Carmichael GJ (1990) Stability of genome size among stocks of the channel catfish. Aquaculture 87:15-22.

Vanparys C, Maras M, Lenjou M, Robbens J, Van Bockstaele D, Blust R, De Coen W (2006) Flow cytometric cell cycle analysis allows for rapid screening of estrogenicity in MCF-7 breast cancer cells. Toxicol In Vitro 20:1238-1248.

Wolf U, Ritter H, Atkin NB, Ohno S (1969) Polyploidization in the family Cyprinidae, order Cypriniformes. I. DNA-content and chromosome sets in various species of Cyprinidae. Humangenetik 7:240-244. 